\title{
Evaluation of Different Marigold Cultivars against Root knot Nematode (Meloidogyne incognita) under Pot Culture Condition
}

\author{
R.S. Mali ${ }^{1}$, N.V. Lavhe ${ }^{2 *}$, R.O. Deotale ${ }^{2}$ and P.R. Panchbhai ${ }^{3}$ \\ ${ }^{1}$ Po. Bhose (k), Tq. Pandharpur, Dist. Solapur, Maharastra, India \\ ${ }^{2}$ Entomology Section, College of Agriculture, Nagpur, Maharastra, India \\ ${ }^{3}$ Agricultural Technical School, Dr. PDKV, Akola, India \\ *Corresponding author
}

Keywords

Marigold, Root knot nematode Meloidogyne incognita, Multiplication

Article Info

Accepted:

17 April 2019

Available Online:

10 May 2019
An experiment was carried out to study the effect of different marigold cultivars viz. African marigold, French marigold, Marigold Gulzafri Yellow, Marigold Gulzafri Orange, Marigold Dhan Basanti and Marigold Hawaii Orange on population and multiplication factors of root knot nematode Meloidogyne incognita in the field of Insectary premises of Entomology section, College of Agriculture, Nagpur during Aug. - Oct. 2017.French marigold Tagetes patula caused significant reduction in the number of root galls ( 8 / plant), root nematode population (29.80 / 8 galls) and soil nematode population $(150.25 / 50 \mathrm{ml})$ with a remarkable growth of tomato plant $(31.5$ $\mathrm{cm}$ ) as compared to other marigold cultivars and control.

\section{Introduction}

Marigold (Tagetes spp.) is used for its nematicidal properties against plant-parasitic nematodes. Marigold can suppress 14 genera of plant-parasitic nematodes, with lesion nematodes (Pratylenchus sp.) and rootknot nematodes (Meloidogyne spp.) as the most affected one ${ }^{[16]}$. The marigold species most often used for nematode control are Tagetes patula, T. erecta, and T. minuta. The key mode by which marigolds suppress plantparasitic nematodes is through a biochemical interaction known as allelopathy. Marigold plants produce a number of potentially bioactive compounds, among which $\alpha$ therthienyl is recognized as one of the most toxic.

This sulfur containing compound is abundant in marigold tissues, including roots. It has nematicidal, insecticidal, fungicidal, antiviral and cytotoxic activities. It is believed to be the main compound responsible for the nematicidal activity of marigold. Rootknot nematodes (Meloidogyne spp.) are one of the 
most widely spread nematode pests parasitizing almost all the crops, grown all over the world. It has been known to cause the diseases of vegetables crops since 1855.There are more than 90 described species in the genus Meloidogyne but the four most commonly occurring species are Meloidogyne incognita, $M$. javanica, $M$. arenaria and $M$. hapla ${ }^{[13][4][2]}$. Among most common species of rootknot nematode, Meloidogyne incognita, is extremely polyphagous and attacks numerous economically important agricultural crops worldwide. The purpose of this work was to evaluate the effect of different marigold cultivars on nematode population multiplication factors.

\section{Materials and Methods}

Root knot nematode Meloidogyne incognita infected soil from field was used. The soil was mixed thoroughly and filled in earthen pots of diameter 12 inches. Seeds of six cultivars of Tagetes viz. Marigold Gulzafri Yellow, Marigold Gulzafri Orange, Marigold Dhan Basanti, Marigold Hawaii Orange, African marigold Tagetes erecta and French marigold $T$. patula was sown at four corners equidistantly at $5 \mathrm{~cm}$ spacing with tomato cultivar (S-22) at centre for evaluation nematode repelling properties. The experiment was laid in quadruplicate in a completely randomized design. Six species was planted in four replication along with tomato seeds. Tomato seedlings alone were used as control plants. Weekly observation was taken on height of each plant for all the treatments. Sixty days after planting each plant was uprooted carefully from soil. The roots were retrieved and kept in a basin of water to clear it from adhering soil particles and recorded the observations on plant growth characteristic (Shoot length), also on nematode multiplication such as number of galls, number of juveniles/plant roots and number of $\mathrm{J} 2 / 100 \mathrm{cc}$ of soil. Roots were spread in big sized petriplate which contained water and recorded the observations on number of galls with the help of the hand lens. Extraction of nematodes for the count of number of juveniles/plants and number of J2/100cc of soil was done by Cobb's Sieving and Decanting method. The extracted nematodes per $\mathrm{ml}$ nematode suspension were counted under stereoscopic binocular microscope with the help of counting dish. The root gall index was calculated from observed number of root galls ${ }^{[13]}$. It is based on scale of 0 to 5 , where $0=$ no galls; $1=1$ to $2 ; 2=3$ to $10 ; 3=11$ to $30 ; 4=31$ to 100 ; and $5=$ more than 100 galls.

\section{Statistical analysis}

The data obtained in respect of nematode population in CRD design was transformed into square root value as per Gomez and Gomez, (1984) and then subjected to statistical analysis to the level of significance of treatment.

\section{Results and Discussion}

This experiment was conducted to study the effect of different marigold cultivars on the reproduction factors of Meloidogyne incognita and plant growth parameter. Observations on nematode reproduction (number of galls/plant, numbers of nematodes in root/plant, soil nematode population and gall index) and plant growth parameter i.e. height of tomato plant before depotting were recorded and presented in table 1 .

\section{Nematodes reproduction factors}

\section{Number of galls per plant}

Results in table 1 and figure 1 showed that the number of galls produced by Meloidogyne incognita on tomato were reduced significantly as compared to check (20 / plant) when it was planted with different cultivars of 
marigold. The minimum number of galls per plant were recorded in treatment $6^{\text {th }}$ plantation with French marigold Tagetes patula (8 / plant) was statistically at par with Marigold Dhan Basanti (10 / plant) followed by Marigold Hawaii Orange (11.75 / plant).

\section{Number of nematodes per plant root}

Data in table 1 and figure 2 revealed that number of nematode population in plant root of tomato were reduced significantly when grown with different marigold cultivars as compared to the control (46.47). The minimum number of nematode population in tomato roots were recorded in $2^{\text {nd }}$ treatment with Marigold Gulzafri Orange (19.40) followed by Marigold Dhan Basanti (24.05) and French Marigold (29.80).

\section{Soil nematode population per 100cc}

Data presented in table 1 and figure 2 revealed that the soil nematode population at harvest was found significantly lower with different Tagetes spp. as compared to control (124.225). The minimum nematode population (93.225) was observed with Marigold Gulzafri Orange followed by Marigold Dhan Basanti (120.475).

\section{Gall index}

Perusal of data in table 1 and figure 4 revealed that gall index was significantly reduced in all the treatments as compared to the control (3.25). The minimum gall index was recorded with French marigold (2.25) as compared to other treatments.

\section{Plant growth parameter}

\section{Plant height}

Data presented in table 1 and figure 3 showed that the plant height was different in each treatment. Tomato grown with different marigold cultivars showed significant increase in the height of tomato plant as compared to control. Among them, maximum plant height was found in the $6^{\text {th }}$ treatment with French marigold Tagetes patula (31.5 $\mathrm{cm})$ followed by African marigold Tagetes erecta $(28.25 \mathrm{~cm})$.

From table 1 it is observed that French marigold Tagetes patula caused significant reduction in the number of root galls, root and soil nematode population with a remarkable growth of tomato plant as compared to other $T$. erecta cultivars and control. It was followed by African marigold T. erecta which showed increased tomato plant height with reduced root galls and nematode population. Earlier workers in accordance with our results reported that $T$. patula cultivars Single Gold and Tangerine and T. erecta Flor de Muerto, when grown within a $20-30^{\circ} \mathrm{C}$ soil temperature range, significantly reduced root galling and nematode infestation of subsequent tomato compared to tomato following fallow ${ }^{[7]}$. The heavy galling and increased nematode infestion in control resulted in stunted growth of tomato.

The strong suppression of $M$. incognita and $M$. javanica by Tagetes patula has been observed elsewhere also reported by some scientists $[6][10][5][3]$. Plants heavily infested with rootknot nematodes exhibited stunted growth $^{[14]}$ and poor yield and in some cases the plants die even before reaching maturity ${ }^{[15]}$.

T. erecta decreased the number of $M$. incognita when it was grown in infested soil $^{[8]}$. At higher soil temperatures, when $M$. incognita is more active and infective ${ }^{[9][12][11]}$, Flor de Muerto, Single Gold and Tangerine marigolds significantly reduced root galling and nematode infection of subsequent tomato compared to the unplanted control. It was also 
observed that $M$. incognita did not form galls when planted with $T$. erecta or $T$. patula and soybean (Glycine max) plants intercropped with these marigold species also had fewer root galls in greenhouse experiments ${ }^{[1]}$.

Table.1 Effect of different marigold culivars against rootknot nematode Meloidogyne incognita (Mean of four replicates)

\begin{tabular}{|c|c|c|c|c|c|c|}
\hline Treatments & $\begin{array}{c}\text { (a) No. of } \\
\text { galls }\end{array}$ & $\begin{array}{c}\text { (b) Roots } \\
\text { nematode } \\
\text { count }\end{array}$ & $\begin{array}{c}\text { (c) Nematode } \\
\text { Population/100 } \\
\text { cc soil }\end{array}$ & $\begin{array}{c}\text { Total } \\
\text { Population } \\
\text { (b+c) }\end{array}$ & $\begin{array}{c}\text { Plant } \\
\text { Height } \\
\text { (cm) }\end{array}$ & $\begin{array}{c}\text { Gall } \\
\text { index }\end{array}$ \\
\hline T1(Marigold Gulzafri & 15.25 & 52.55 & 139.15 & 191.7 & 16.5 & 2.75 \\
Yellow) & $(3.96)$ & $(7.28)$ & $(11.81)$ & $(13.86)$ & & \\
\hline T2(Marigold Gulzafri & 13.75 & 19.40 & 93.225 & 112.625 & 21 & 2.5 \\
Orange) & $(3.77)$ & $(4.46)$ & $(9.68)$ & $(10.63)$ & & \\
\hline T3(Marigold Dhan & 10 & 24.05 & 120.475 & 144.525 & 17.75 & 2.5 \\
\hline Basanti) & $(3.24)$ & $(4.95)$ & $(10.99)$ & $(12.04)$ & & \\
\hline T4(Marigold Hawaii & 11.75 & 56.15 & 270.975 & 327.125 & 26 & 2.5 \\
\hline Orange) & $(3.5)$ & $(7.52)$ & $(16.47)$ & $(18.10)$ & & \\
\hline T5(African Marigold) & 12.75 & 30.25 & 145.825 & 176.075 & 28.25 & 2.5 \\
\hline T6(French Marigold) & $(3.64)$ & $(5.54)$ & $(12.09)$ & $(13.28)$ & & \\
\hline T7(Control - Tomato) & 8 & 29.80 & 150.250 & 180.05 & 31.5 & 2.25 \\
& $(2.91)$ & $(5.50)$ & $(12.27)$ & $(13.43)$ & & \\
\hline S.Ed. & $(4.52)$ & 46.47 & 124.225 & 170.695 & 14.75 & 3.25 \\
\hline CD & $(6.85)$ & $(11.16)$ & $(13.08)$ & & \\
\hline & 0.84 & 1.37 & 3.50 & & & \\
\hline
\end{tabular}

(Figures in parentheses are $\sqrt{x+0.5}$ values)

Fig.1\&2 Number of galls on tomato roots \& nematode population in tomato roots and soil

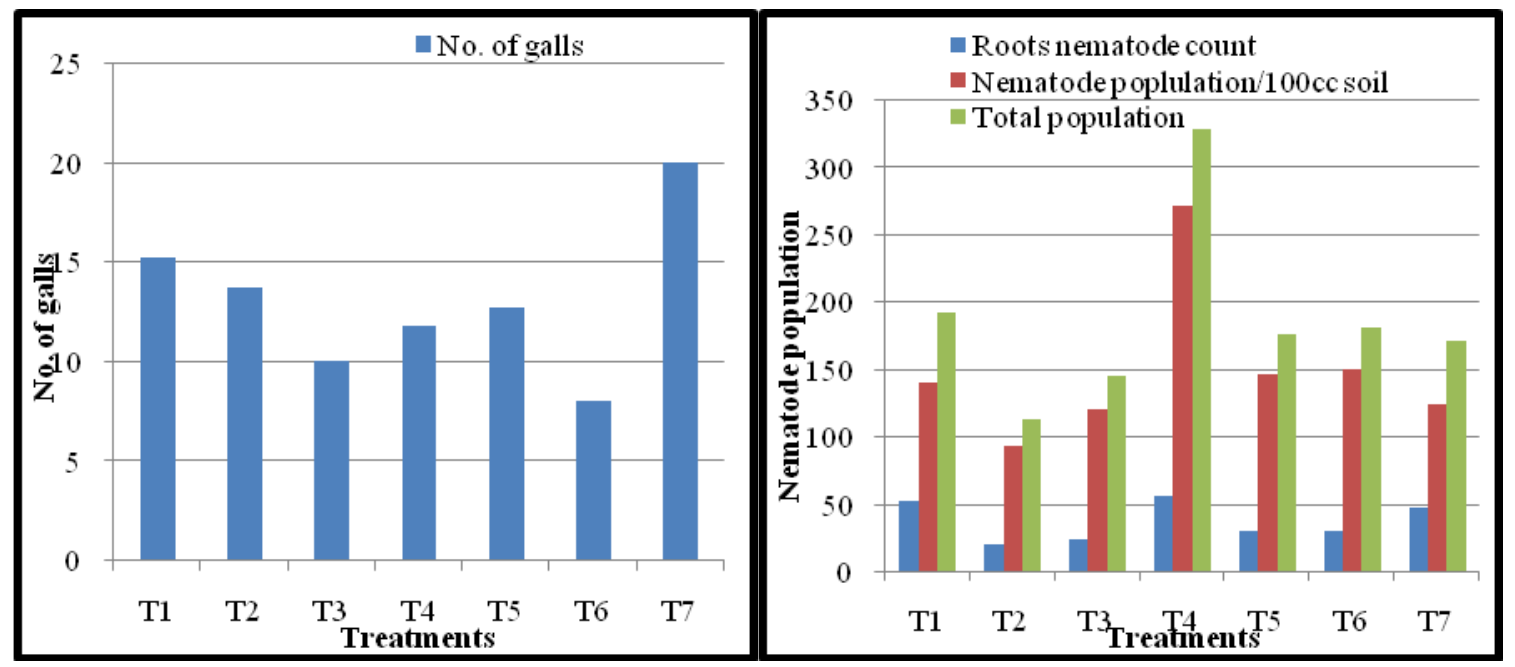


Fig.3\&4 Tomato plant height after 60 days and Tomato root gall index

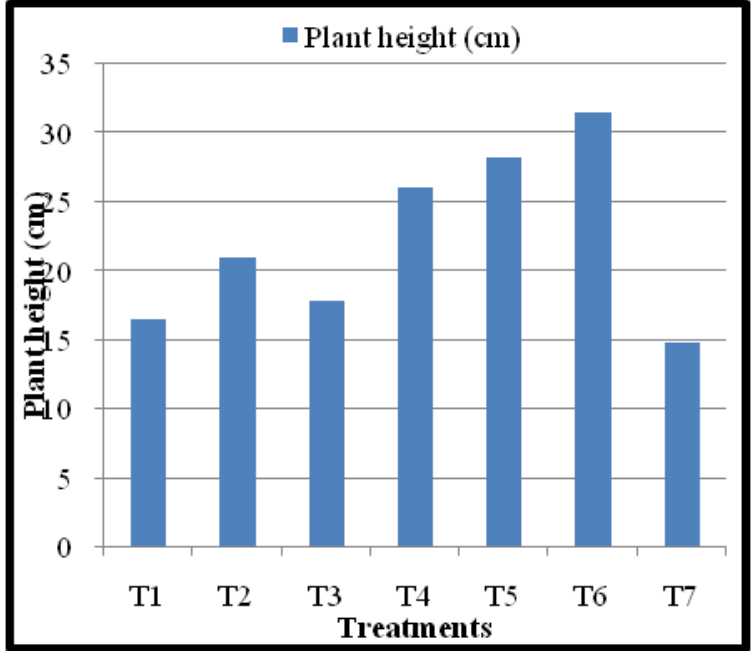

In conclusion, french marigold Tagetes patula caused significant reduction in the number of root galls (8 / plant), root nematode population (29.80 / 8 galls) and soil nematode population $(150.25 / 50 \mathrm{ml})$ with a remarkable growth of tomato plant $(31.5 \mathrm{~cm})$ as compared to other marigold cultivars and control. Considering the Eco-friendliness, it can be stated that the planting of antagonistic plant like French marigold Tagetes patula instead of chemical nematicides effectively reduces the root galls and nematode multiplication with healthy plant growth. Hence, these marigold cultivars can be included in nematode management without any adverse effect on agroecosystem.

\section{References}

1. El-Hamawi, M. H., M. M. A. Youssef and H. S. Zawam. Management of Meloidogyne incognita, the root-knot nematode, on soybean as affected by marigold and sea ambrosia (damsisa) plants. J Pest Sci. 2004; 77: 95-98.

2. Hunt, A. P., S. G. Lucas, and J. A. Spielmann. Early Permian vertebrate coprolites from north-central New Mexico: New of Natural History and Science, Bulletin 2005; 31: 43-45.

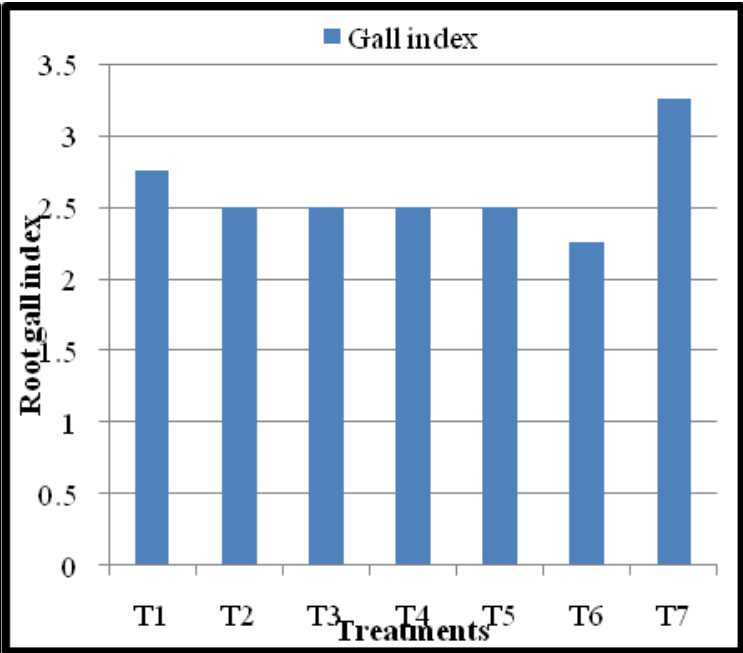

3. Kagundu, A. M. Effect of green manure plants on root knot nematodes (Meloidogyne spp) infecting common bean (Phaseolus vulgaris L.) M.Sc. (Thesis) University of Nairobi 2001.

4. Karssen, G. The plant parasitic nematode genus Meloidogyne in Europe. Brill Academic Publishers, Leiden, The Netherlands 2000; 161 pp.

5. Mateeva, A., M. Ivanova, M. L. Gollino, J. Katan and A. Matta. Alternative methods of control of rootknot nematodes Meloidogyne spp. Proceedings of the $5^{\text {th }}$ International Symposium on Chemical and nonChemical soil substrate Disinfestation, Torino, Italy 2000; 532: 109-111.

6. McSorley, R. and J. J. Fredrick. Response of some common annual bedding plants to three species of Meloidogyne. Supplement to the Journal of Nematology 1999; 26:773-777.

7. Ploeg, A. T. Greenhouse Studies on the Effect of Marigolds (Tagetes spp.) on Four Meloidogyne Species. Journal of Nematology 1999; 31(1): 62-69.

8. Prasad, D., D. K. Nagla, S. Kumar and M. L. Saini. Marigold plants for management of nematode populations 
in fields. Current Nematology 1992; 3: 15-18.

9. Prot, J. C. and S. D. Van Gundy. Effect of soil texture and the clay component on the migration of Meloidogyne incognita second-stage juveniles. Journal of Nematology 1981; 13: 213217.

10. Reynolds, L. B., J. W. Potter and C. B. R. Ball. Crop rotation with Tagetes spp.is an alternative to chemical fumigation for control of root lesion nematodes. Agronomy Journal 2000; 92: 957-966.

11. Roberts, M. G. and B. T. Grenfell. The population dynamics of nematode infections of ruminants: periodic perturbations as a model for management. IMA J Math Med Biol. 1991; 8(2): 83-93.

12. Roberts, P. A. The influence of date of planting of carrot on Meloidogyne incognita reproduction and injury to roots. Nematologica 1987; 33: 335-342.

13. Sasser, A. L. and A. L. Taylor. Biology, identification and control of rootknot nematodes Meloidogyne species. Dept. of Plant Pathology AID, Washington, DC (EUA). 1978.

14. Siddiqui, M. A. and M. M. Alam. Further studies on the nematode toxicity of different parts of Margosa and Persian lilac. Neem Newslett 1985; 2 : 43-47.

15. Singh, S. K. and R. K. Khurma. Susceptibility of six tomato cultivars to the root-knot nematode Meloidogyne incognita. The South Pacific Journal of Natural Sciences 2007; 13: 73-77.

16. Suatmadji, R. W. Studies on the effect of Tagetes species on plant parasitic nematodes. Wageningen, The Netherlands: H. Veenman en Zonen. 1969.

\section{How to cite this article:}

Mali, R.S., N.V. Lavhe, R.O. Deotale and Panchbhai, P.R. 2019. Evaluation of Different Marigold Cultivars against Rootknot Nematode (Meloidogyne incognita) under Pot Culture Condition. Int.J.Curr.Microbiol.App.Sci. 8(05): 2130-2135. doi: https://doi.org/10.20546/ijcmas.2019.805.249 